\title{
The barred grunt Conodon nobilis (Perciformes: Haemulidae) in shallow areas of a tropical bight: spatial and temporal distribution, body growth and diet
}

\author{
Maíra Pombo • Márcia Regina Denadai • \\ Eduardo Bessa • Flávia Borges Santos • \\ Vanessa Hermann de Faria • Alexander Turra
}

Received: 2 September 2013/Revised: 14 January 2014/Accepted: 12 February 2014/Published online: 27 February 2014

(c) Springer-Verlag Berlin Heidelberg and AWI 2014

\begin{abstract}
This study aimed to comprehensively investigate the population biology of Conodon nobilis (Perciformes, Haemulidae) in Caraguatatuba Bight, southeastern Brazil. Monthly trawls were performed from October 2003 through October 2004 in two areas of the bight that are similar to but distant from each other, South and North. For all specimens, the size was measured and the sex and reproductive stage identified. Abundance and size were compared over areas and months. Body growth parameters were parameterized according to the Von Bertalanffy growth function. The stomach contents were identified and quantified. C. nobilis occurred mainly in the North area and showed an erratic pattern of abundance over time. Several
\end{abstract}

Communicated by A. Malzahn.

M. Pombo $(\bowtie) \cdot$ A. Turra

Instituto Oceanográfico da Universidade de São Paulo, Praça do Oceanográfico 191, São Paulo 05508-120, Brazil

e-mail: mairapombo@gmail.com

M. R. Denadai

Centro Universitário Módulo, Av. Frei Pacífico Wagner 653,

Caraguatatuba, SP 11660-903, Brazil

E. Bessa

Laboratório de Ecologia Comportamental da Reprodução,

Universidade do Estado de Mato Grosso, Rodovia

MT358 km 07, Tangara da Serra, MT 78300-000, Brazil

F. B. Santos

Departamento de Ciências Naturais, Universidade Estadual do Sudoeste da Bahia, Estrada do Bem Querer, km 04,

Vitória da Conquista, BA 45083-900, Brazil

V. H. de Faria

Centro Universitário da Fundação de Ensino Octávio Bastos, Rua General Osório 433, São João da Boa Vista, SP 13870-431, Brazil cohorts entered in different periods, but very few large and mature individuals were observed. The results indicate a preference for shallow, ocean-influenced habitats and some degree of segregation between young and older individuals. The species showed a distribution consistent with an r-strategist species, with high abundance and a high growth constant $\left(K=0.68\right.$ year $^{-1}$ and $\left.L_{\max }=34.2 \mathrm{~cm}\right)$. Both the relative length of the digestive tube and the prey items indicated a carnivorous feeding habit; mysids were the main item of the diet throughout the study period, indicating that this grunt is a specialist feeder. Other frequently observed items were amphipods and fish fragments. Ingestion of scales is possibly intentional.

Keywords Spatio-temporal distribution - Size ·

Abundance $\cdot$ Body growth $\cdot$ Mysida

\section{Introduction}

Studies of ichthyofauna communities have been carried out widely in tropical areas, especially concerning the effects of shrimp trawling in coastal areas and the enormous numbers of fish uselessly killed by this activity (Crowder and Murawski 1998; Branco and Verani 2006). Efforts to understand these specific fish populations are rarer, since most community studies target commercially important species. The varied human pressures on coastal areas in addition to shrimp trawling are of great concern, and the clearest responses to environmental changes may come from species that are not commercially important. This contribution presents a study of broad aspects of the population biology of the barred grunt Conodon nobilis, an often abundant and widely distributed species along the Atlantic coasts of the Americas (Menezes and Figueiredo 1980; Cervigón et al. 1992). 
Grunts are members of the family Haemulidae and receive their common name from the loud noise that they produce by rubbing their teeth together and amplified by the swim bladder. Few species of the family have commercial importance. Many are inhabitants of coral reefs and rocky shores (mainly the genera Haemulon and Anisotremus). Many genera, however, are more typical of brackish waters and sandy bottoms, such as Pomadasys, Orthopristis and Conodon (Menezes and Figueiredo 1980). Members of Conodon are the barred grunts, of which Conodon nobilis is the only species in the western Atlantic (Konchina 1977). It occurs from Texas in the southern USA to Santa Catarina in southern Brazil and is very common in demersal assemblages of sandy coastal areas, but also occurs along rocky shores and in brackish and estuarine waters, mostly recorded using surf zones rather than estuaries as nursery areas (Oliveira 1974; Menezes and Figueiredo 1980; Godefroid et al. 2004; Barletta et al. 2005; da Santana and Severi 2009; de Dantas et al. 2012). Knowledge of $C$. nobilis is derived basically from studies on demersal assemblages, in some cases with notes on the influence of abiotic factors on its distribution (Godefroid et al. 2004; da Santana and Severi 2009; de Dantas et al. 2012).

Assessments of the diet of $C$. nobilis have indicated a preference for benthic animals, especially crustaceans (Lopes and Oliveira-Silva 1998; Feitosa et al. 2002), but identified only broad prey taxa, and none has assessed temporal changes in diet composition. Although the diets of many members of demersal fish assemblages may appear very similar, a meticulous assessment of prey items may reveal peculiarities in sharing resources among the competitors (Pombo et al. 2013).

Life-history traits of a species reveal the influences of environmental pressures. Differential, irregular population fluctuations, decreases in growth rates, changes in spawning periods, competition and prey-predator interactions, among others, must be determined and tracked if effective management actions are to be implemented (Walters and Post 1993; Anderson 2001; King and McFarlane 2003; Rouyer et al. 2012). Although C. nobilis is common in shallow coastal areas, studies of the population biology of this species are few.

Here, the population biology of $C$. nobilis was assessed in shallow areas in an important tropical bight in southeastern Brazil, Caraguatatuba Bight. Despite the economic and ecological importance of this area, the local ichthyofauna is largely unstudied. The basic biological data obtained in this study provided the first broad and detailed scientific information on this species. The study was part of a broad evaluation of the fish and mega-epifauna in the area, which will constitute the main baseline for future comparisons, as mandated by State Law No. 49,215 of 7
December 2004, which established ecological-economic zones (EEZ). Following that evaluation, Caraguatatuba Bight was characterized as Z2ME (Marine Zone Special Category 2), with the result that trawling was totally prohibited. This knowledge of baseline conditions may be useful to identify possible future changes in the benthic and fish communities.

\section{Materials and methods}

Study area and sampling procedures

Caraguatatuba Bight $\left(23^{\circ} 37^{\prime} \mathrm{S}-23^{\circ} 44^{\prime} \mathrm{S}\right.$ and $45^{\circ} 24^{\prime} \mathrm{W}-$ $45^{\circ} 26^{\prime} \mathrm{W}$ ), actually a large bight, is $16 \mathrm{~km}$ long and contains several sandy beaches (Enseada, Flecheiras, Porto Novo, Romance, Palmeiras, Pan-Brasil, Indaiá, Centro and Camaroeiros; Fig. 1). Two separate areas, each measuring $2.0 \times 0.8 \mathrm{~km}$ and as similar as possible, were termed South and North. These areas were selected to avoid the influence of rivers on the samples (Fig. 1). Rivers are typically small in this part of the country (northern coast of São Paulo), although Juqueriquerê has the largest basin (Souza 2005). The sampling areas were as representative as possible of the shallow areas of the bight, with relatively little continental influence.

Samples were taken monthly from October 2003 through October 2004. In each area, a section of beach $2,000 \mathrm{~m}$ long was divided into $10-\mathrm{m}$ intervals, and three sampling stations were randomly selected from these 200 possibilities at each sampling event. The position of the station was stored in a GPS at MLW (mean low water). From this point, a fishing boat (class G2 M, $11 \mathrm{~m}$ long with a 22-HP engine) performed $800-\mathrm{m}$ trawls perpendicular to the beach, starting at a point 400-1,600 $\mathrm{m}$ distant from the MLW line. This interval is equivalent to depths from 1 to $4 \mathrm{~m}$. The trawling speed was $1 \mathrm{kt}$, performed with a bottom otter trawl with $2.0 \mathrm{~cm}$ mesh, mouth aperture $1.6 \mathrm{~m}$ high and $6.0 \mathrm{~m}$ long, and bag depth $3.5 \mathrm{~m}$.

The fish were removed from net and immediately preserved in a $10 \%$ formalin solution in order to paralyze the enzyme action, preserving the digestive-tube contents. Specimens of $C$. nobilis were sorted, preserved in $70 \%$ ethanol and measured (total length, cm). A total of 160 individuals were randomly selected from the total catch. In these specimens, ventro-sagittal abdominal incisions were made and the sex and female gonadal stage determined, according to traditional identification guides (Vazzoler 1996), as follows: immature (translucent ovary, no oocytes visible to the naked eye), maturing (ovary with noticeable capillary net, small to medium oocytes visible to the naked eye) and mature (turgid ovaries with big-translucent or opaque-oocytes). Flaccid, recent emptied gonads were 
Fig. 1 Caraguatatuba Bight and the sampling scheme (dashed lines) from a monthly sample in two study areas, North and South (solid lines)

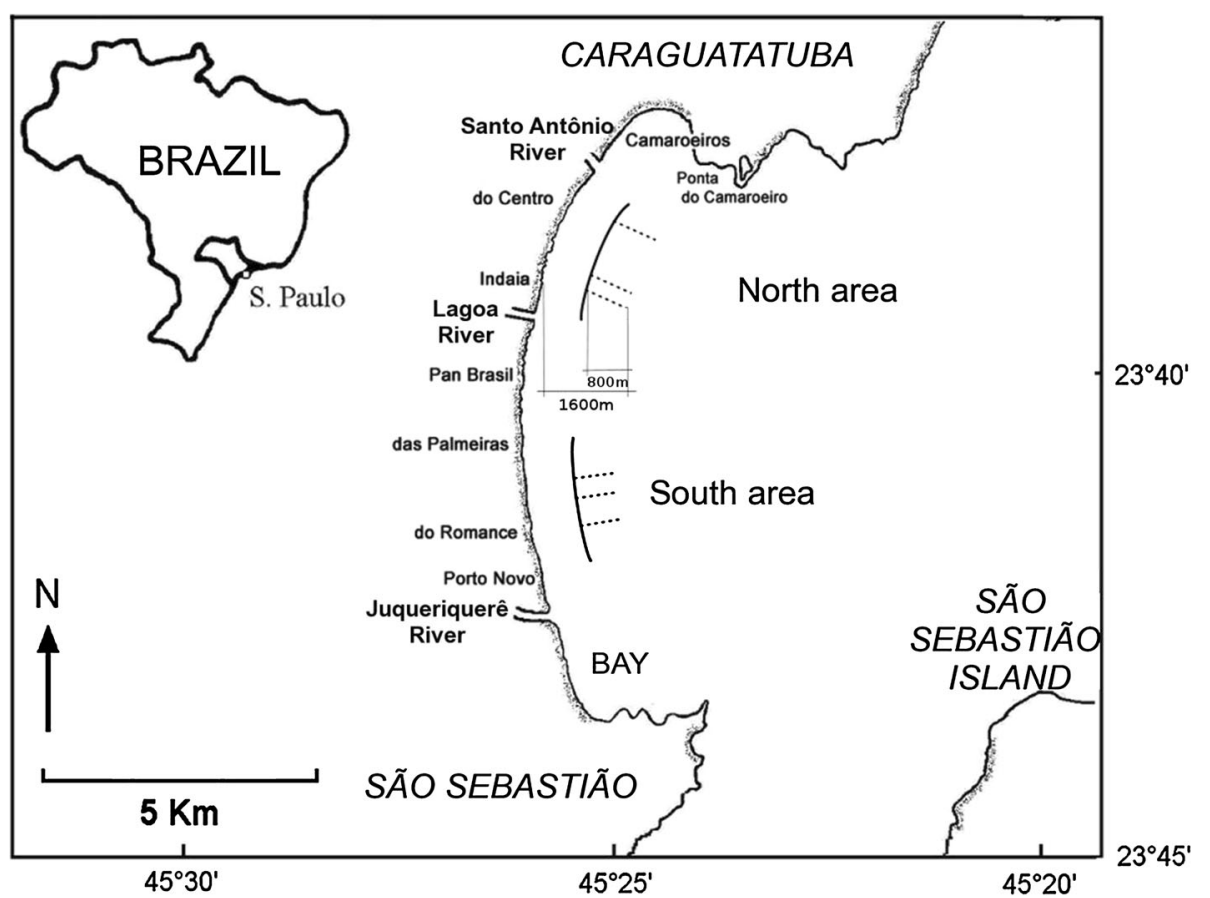

The variation in total length over time was also used to parameterize the VBGM for this population of $C$. nobilis. Because the length of the largest individual collected was below the maximum length recorded in previous studies (33.6 cm TL; Cervigón et al. 1992), literature values were used as a basis to define an asymptotic length $\left(L_{\infty}\right)$ range to perform the analysis. This range was defined by setting the literature reported value as the lower limit, and its division by 0.95 (Taylor 1958; Beverton 1963) as the upper limit.

From this point on, both the traditional approach (best goodness-of-fit value, considering oscillation modification of the VBGM, as proposed by Pauly and Gaschutz 1979) and a visual one (which took into account biological features of the species and the particularities of the area) were performed. For the former, we used the ELEFAN I routine of the FISAT package. For the latter, identifiable cohorts were visually assessed, and the slopes that reliably covered as many different cohorts as possible were plotted. Lastly, both approaches were combined, by assessing the best values of Rn among all feasible slopes visually identifiable, which was considered the most suitable to parameterize the VBGM for this population.

Empirical formulas were used to estimate $t_{0}$ (Pauly 1979) and $t_{\max }$ (longevity; (Pauly 1983a), respectively: log$t_{0}=-0.3922-\left(0.2752 \log L_{\infty}\right)-(1.038 \log K)$ and $t_{\max }=t_{0}+2.9957 / K$.

By replacing the estimated variables in the Von Bertalanffy growth function and isolating $t$, it was possible to estimate the age of individuals at some of the key TL values (minimum, maximum, mean) in the population. The key-parametric). 


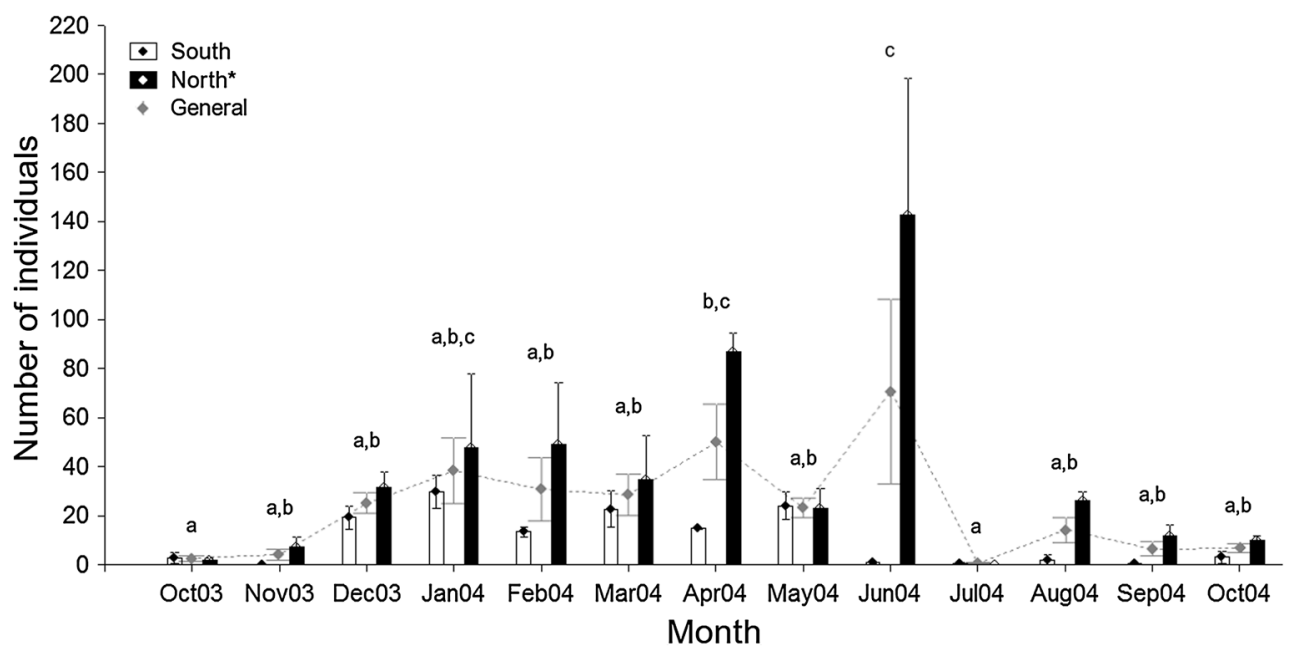

Fig. 2 Spatial and temporal variations in the number of individuals (mean \pm standard error; $\alpha=0.05$ ) of Conodon nobilis in Caraguatatuba Bight, from August 2003 through October 2004. Different letters denote significant differences among months and areas,

total mortality coefficient $(Z)$, which basically measures the rate at which the number of individuals decreases over time, was estimated by FISAT software by the lengthconverted catch curve, as proposed by Pauly (1983b).

The relationship between the fish digestive tube and body length was assessed (DTTL/TL). Concerning the dietary analysis, for each stomach item, the frequency of occurrence (FO) and percent volume $(V)$ were calculated seasonally. The values of FO or $\mathrm{V}$ higher than $5 \%$, for each prey category in any season, were used in scatter plots as proposed by Costello (1990), and in the calculation of an index of dietary importance (IAi), as proposed by Kawakami and Vazzoler (1980): $\mathrm{IA}_{i}=\mathrm{FO}_{i} \times V_{i} / \Sigma\left(\mathrm{FO}_{i} \times V_{i}\right)$.

\section{Results}

A total of 1,817 individuals of $C$. nobilis were collected. The species was more abundant in the North area throughout the period, except for October 2003 and May 2004, when a slight predominance was observed in the South area. The most pronounced discrepancy in abundance of specimens between areas was recorded in June 2004, when only two individuals were collected in the South area.

Overall, the abundance of $C$. nobilis was low during the first two sampling months. In December 2004, the mean number of individuals increased about threefold and remained at about that level until May 2004. The highest abundance occurred in June, remarkably followed by an absence of individuals in July. During the last 3 months, the number of individuals remained steady, and the fish were found almost exclusively in the North area. discriminated by SNK test; absence of letters indicates no difference from any other value. Gray markers represent the total number of individuals sampled in each month

Statistical analysis showed no interaction between the factors space and time $(H=13.37 ; d f=12 ; p=0.32)$. However, abundance was significantly higher in the North area $(H=10.43 ; d f=1 ; p<0.01)$ and also over time $(H=41.60 ; d f=12 ; p<0.01)$. The species was least abundant in October 2003 and July 2004, and most abundant in June 2004. Intermediate differences were observed for the other months, where January did not differ from any other, April did not differ from the highest value and all other months did not differ from the lowest (Fig. 2).

The total length (TL) of individuals ranged from 4.9 to $18 \mathrm{~cm}$, with an overall mean of $10.38 \mathrm{~cm}( \pm 0.06 \mathrm{SE})$ and a wide general mode $(8-12 \mathrm{~cm}$; Fig. 3$)$. Observing the size distribution of each area separately, we see that in the South area the distribution was skewed to left (Fig. 3a) in comparison to North area (Fig. 3b). Accordingly, there was a statistically significant difference between areas (South area normality $W=0.958, \quad p<0.01$; North area $W=0.985, p<0.01 ; p$ variances $=0.70 ; U=233,667$; $n=1,817 ; p<0.001$ ), with lower values for the South area. In the temporal analysis, significant differences among months were observed, as shown by the one-way ANOVA (Cochran $p=0.05 ; F=6.5 ; d f=12 ; p<0.05)$; the lowest values of size were identified in December 2003, and the highest in October 2003, May-June, August and October 2004. All other mean values did not differ from each other (Fig. 4).

For a general overview of temporal shifts of fish size, further comparisons treat the fluctuations in mean size (Fig. 4) together with monthly size histograms (Fig. 5). The mean size in October 2003 was around $10 \mathrm{~cm}$ and in November increased to $11 \mathrm{~cm}$. Since in November individuals were sampled only in the North area, statistical 
Fig. 3 Total length $(\mathrm{cm})$ class distribution for Conodon nobilis sampled in Caraguatatuba Bight October 2004 from August 2003 through

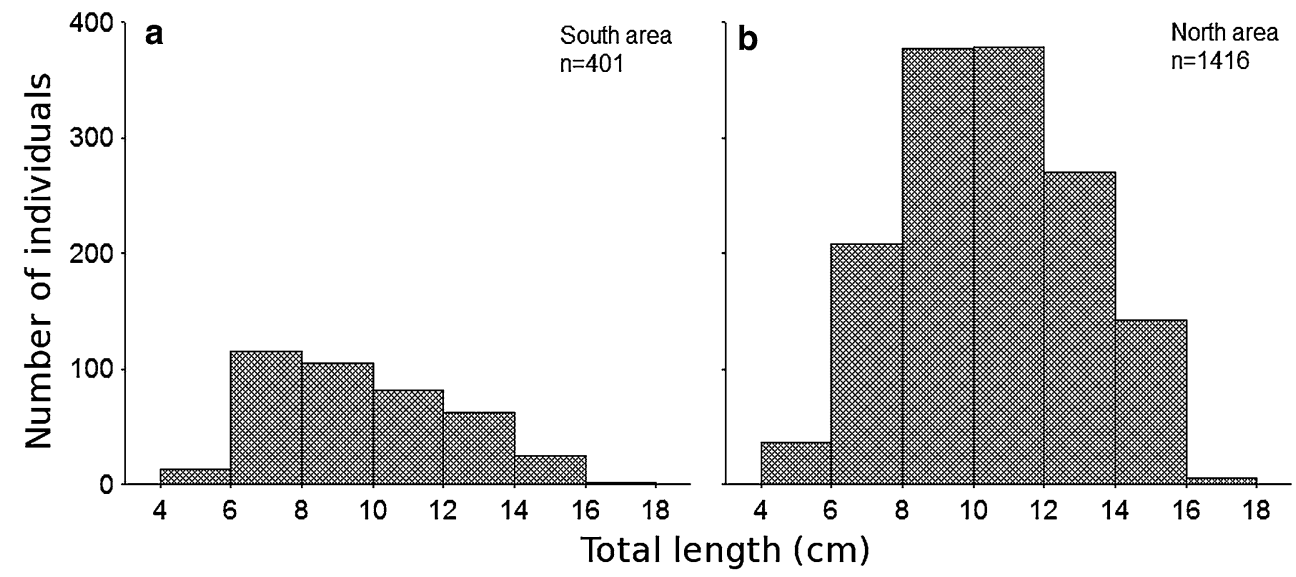

Fig. 4 Temporal variation of total length $(\mathrm{cm})$ (mean \pm standard error; $\alpha=0.05$ ) for Conodon nobilis sampled in Caraguatatuba Bight from August 2003 through October 2004, using areas as replicates $(n=2)$. Different letters denote significant differences among months, discriminated by Tukey's test

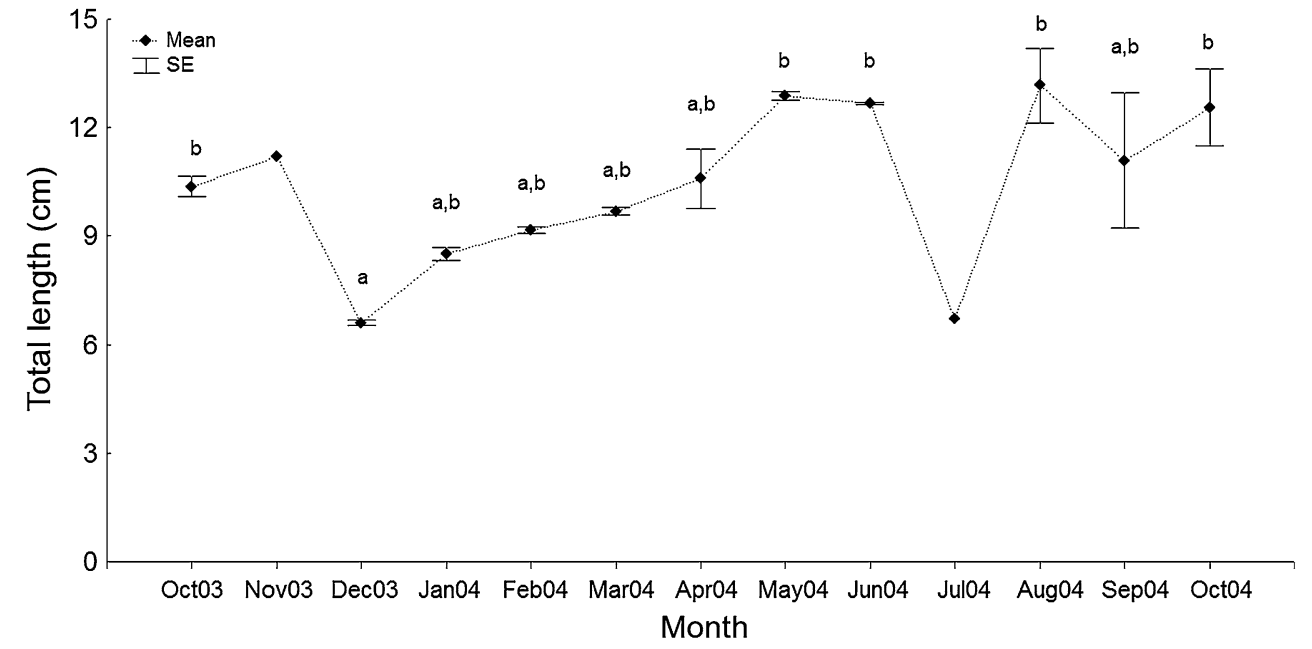

comparisons were not viable for this month. It is clear, though, that these values correspond to the single TL mode observed in the histograms of the respective months. In December, the mean TL value decreased to about $6.5 \mathrm{~cm}$. This decrease in the mean value matches with the entrance of a new cohort, identified through a new mode, which gradually increased in size until June 2004 (Fig. 5). In March 2004, the entrance of a new cohort was again observed. From this point on the distribution of size, classes became bimodal. Since this second cohort also showed an increasing modal progression until June, the mean values also increased gradually. Given the large numbers of individuals and the similar size structure between areas, during May and June 2004, the mean TL values were high and showed small deviations. After a small number of individuals entered in June 2004, the higher mean TL values remained more or less constant from August through October 2004. However, with the reduction in the number of individuals and the lack of evident modes, greater deviations began to be observed.
A viable parameterization of the VBGM was indicated by the similar fluctuations of scores, according to $K$ values, of both Sheperd's and Elefan K-scans. The best goodnessof-fit value $(\mathrm{Rn}=0.323)$ was linked to a value of $K$ of 0.08 year $^{-1}\left(L_{\infty}=33.5 \mathrm{~cm}, C=0.3, \mathrm{WP}=0.5\right)$. The curve associated with this result, though, clearly reflects the cohort that entered the area in December 2003, as well as the one that entered in April 2004 (Fig. 5). Since a clear entrance of individuals in certain periods was observed, as well as a gradual modal progression for each of them, a new analysis was performed, disregarding only the best value of $\mathrm{Rn}$. Among the slopes that covered the identified cohorts appropriately, the one with the best value of $\mathrm{Rn}$ corresponds to the following parameters: $K$ equal to $0.68 \mathrm{year}^{-1}$, for a $L_{\infty}$ of $34.2 \mathrm{~cm}$, corresponding to an $\mathrm{Rn}$ value of 0.160 (Fig. 5). We considered the parameter $C$ as 0 (and consequently WP). Since it is a tropical area and individuals were predominantly young, no significant oscillation on body growth should be expected. Based on these values, $t_{0}$ amounts to -0.23 years, which is empiri- 


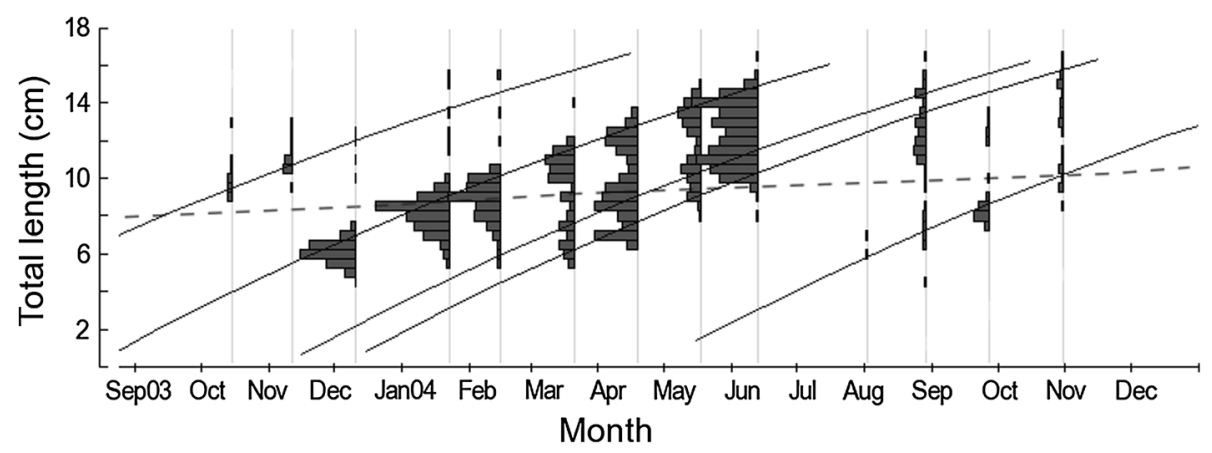

Fig. 5 Illustration of the Von Bertalanffy growth function parameterized for Conodon nobilis individuals sampled in Caraguatatuba Bight from August 2003 through October 2004, using the ELEFAN I routine. The dashed line represents the parameterization with the highest goodness-of-fit value- $L_{\infty}$ (maximum length) $33.5 \mathrm{~cm}$,

cally equal to a maximum age of 4.18 years. This means that when individuals of $C$. nobilis started to enter the area $(4.9 \mathrm{~cm} \mathrm{TL})$, they were about 81 days old. The mean length $(10.36 \mathrm{~cm})$ corresponds to an age of 6 months and 11 days, and the oldest individuals observed $(18 \mathrm{~cm})$ were about 1 year and 3 months older. The total mortality coefficient of $27.96\left( \pm 3.84 \mathrm{SD} ; r^{2}=0.96\right)$ was high, in accordance with the small number of older individuals in the samples.

Analysis of the sexual maturation stages of $C$. nobilis in Caraguatatuba Bight revealed that most specimens were still young and had not reached the size at first maturation. Of the 160 individuals analyzed, 149 were immature. All of the 11 individuals with gonads in maturation were males.

Concerning its diet, $C$. nobilis showed a mean DTTL/TL ratio of $0.64( \pm 0.18 \mathrm{SD})$. A total of 7 different prey categories were identified, plus acanthocephalans, which were considered parasites. Most of the items were observed only occasionally and were characterized as rare (Table 1). Non-identified organic matter was included in the $\mathrm{IA}_{i}$ due to its high frequency of occurrence, but not in further analyses since it does not convey important biological meaning. Crustaceans and fish were the only groups that stood out in importance. Eight different groups of Crustacea were identified, of which Mysida was by far the most important $(\mathrm{FO}=83 \%$ and $V=63 \%)$, followed by Amphipoda, which occurred in about $20 \%$ of the stomachs, but had a low percent volume $(1.7 \%)$. Teleost prey was identified mainly by scales, but also by some other body fragments. The seasonal characterization (Fig. 6) showed that the feeding habits of $C$. nobilis remained stable over time. Mysida was the main item in all seasons, i.e., over $50 \%$ in both frequency and volume in the stomachs. Fish scales were the second main item, but only in relation to occurrence, since they generally comprised less than $20 \%$ by volume, reaching $33 \%$ in spring. All other items,
$C=0.3, \quad$ WP $=0.5 ; \quad K \quad$ (growth curve parameter) $=0.08$, $\mathrm{Rn}=0.323$, and the solid lines represent the parameterization performed via visual identification of modal progressions$L_{\infty}=34.2 ; K=0.68, \mathrm{Rn}=0.160$

including Amphipoda, were characterized graphically as occasional prey, in all seasons.

\section{Discussion}

The clear preference of $C$. nobilis for the North area concords with a preference for more oceanic waters. Although both areas were selected so as to avoid the influence of continental waters, the South area is closer to a larger river, the Juqueriquerê River, and therefore prone to stronger continental influence during rainy seasons (Souza 2005). Previous studies first indicated the occurrence of $C$. nobilis in brackish and estuarine waters (Konchina 1977). More recently, though, this grunt has been shown to be predominant in the surf and shallow zones of sandy beaches, including mud and rock bottoms (Menezes and Figueiredo 1980; Godefroid et al. 2004). Oliveira (1974) also included this species among those that are marine and do not enter estuarine waters.

The variability in abundance was somewhat similar to that identified by another study, in a shallow coastal zone in southern Brazil (Godefroid et al. 2004). There, C. nobilis was more abundant in summer and autumn, and the authors did not record the species for several months, in contrast to a high abundance in other months. This fluctuation in abundance may be normal for the species' dynamics, at least in similar environments.

With respect to the size structure of the population, as shown in the general histogram, almost all individuals caught were $6-15 \mathrm{~cm}$ long. The known maximum length of this croaker is over $30 \mathrm{~cm}$ (Konchina 1977; Menezes and Figueiredo 1980). A closer look at the monthly histograms shows that this overall picture was composed by a bimodal distribution most of the time, each mode with its own gradual progression during the year. Since almost all 
Table 1 Frequency of occurrence (FO \%), percent volume $(V \%)$, and alimentary importance index $\left(\mathrm{IA}_{i}\right)$ of the items identified in the stomach contents of Conodon nobilis $(n=160)$ sampled in Caraguatatuba Bight from October 2003 through October 2004

\begin{tabular}{|c|c|c|c|}
\hline Dietary items & FO $(\%)$ & $V(\%)$ & $\mathrm{IA}_{i}$ \\
\hline \multicolumn{4}{|l|}{ Phylum Cnidaria } \\
\hline Hydrozoa n.i. & 1.91 & 0.02 & 0.00048 \\
\hline \multicolumn{4}{|l|}{ Phylum Sipuncula } \\
\hline Sipuncula n.i. & 1.91 & 0.03 & 0.00097 \\
\hline \multicolumn{4}{|l|}{ Phylum Echiura } \\
\hline Echiura n.i. & 0.64 & 0.01 & 0.00006 \\
\hline \multicolumn{4}{|l|}{ Phylum Mollusca } \\
\hline \multicolumn{4}{|l|}{ Class Bivalvia } \\
\hline Bivalve siphons & 1.91 & 0.08 & 0.00213 \\
\hline \multicolumn{4}{|l|}{ Phylum Annelida } \\
\hline Polychaeta n.i. & 1.91 & 0.05 & 0.00145 \\
\hline Polychaete tubes & 1.27 & 0.03 & 0.00058 \\
\hline \multicolumn{4}{|l|}{ Phylum Arthropoda } \\
\hline $\begin{array}{l}\text { Crustacean fragments } \\
\text { Class Branchiura }\end{array}$ & 13.38 & 1.12 & 0.22030 \\
\hline Branchiura n.i. & 0.64 & 0.00 & 0.00003 \\
\hline \multicolumn{4}{|l|}{ Class Malacostraca } \\
\hline Crab n.i. & 1.27 & 0.40 & 0.00749 \\
\hline Mysida n.i. & 83.44 & 63.50 & 78.07830 \\
\hline Amphipoda n.i. & 16.56 & 0.41 & 0.10071 \\
\hline Amphipod tubes & 20.38 & 1.30 & 0.39147 \\
\hline Isopoda n.i. & 0.64 & 0.04 & 0.00039 \\
\hline \multicolumn{4}{|l|}{ Phylum Bryozoa } \\
\hline Bryozoa n.i. & 1.91 & 0.01 & 0.00039 \\
\hline \multicolumn{4}{|l|}{ Phylum Chordata } \\
\hline \multicolumn{4}{|l|}{ Class Pisces } \\
\hline Fish fragments & 4.46 & 10.63 & 0.69840 \\
\hline Fish scales & 62.42 & 14.15 & 13.02001 \\
\hline \multicolumn{4}{|l|}{ Others } \\
\hline Organic matter n.i. & 61.78 & 8.21 & 7.47680 \\
\hline Total & & 100 & 100 \\
\hline
\end{tabular}

individuals were small-sized, one could speculate about differential mortality. However, given that the fish were not only small but also mostly immature, together with their high abundance and the observed entrance of new cohorts during the study period, it seems more reasonable to consider that the adults could be somewhere else, as previously suggested for other species from the area (Pombo et al. 2012). Further, segregation between adults and young of Haemulidae is often observed over daily cycles, and the adults are typically inactive during daylight (Randall 1967).

Regardless of the possible degree of segregation of juveniles from older individuals, this feature tends to indicate a high mortality. The growth constant obtained indicates rapid body growth, a condition also observed by Garcia and Duarte (2006). Members of Haemulidae may reach 7 years of age, and mature sexually at around 2-3 years of age (Konchina 1977). Since we are dealing with a small-sized species in a tropical population, the empirically estimated maximum age of 4.18 years is reasonable. Also, most fish in the area were not sexually mature and were estimated as less than 1 year old. The peculiarities of this population must be treated with caution because of the virtual absence of larger individuals, which may have biased the curve after a certain point. However, the use of literature values rather than the observed one to estimate the asymptotic length was an important factor in minimizing this effect.

In $C$. nobilis, the length of the digestive tube in relation to the total length (DTTL/TL) is characteristic of a typical carnivorous habit $(<1$; Karachle and Stergiou 2010). The few reports on feeding habits of this species showed that the main prey items are mainly crustaceans (Lopes and Oliveira-Silva 1998; Feitosa et al. 2002). The high and constant importance of mysids in the diet, observed here, is interesting since other studies did not find mysids among the food items. Although the local plankton community has not been studied, in other fish species the diet composition shifted considerably from season to season (Denadai et al. 2013; Pombo et al. 2013), which indicates that $C$. nobilis may indeed have a strong preference for mysids and supports its characterization as a specialist feeder, at least as late juveniles $(5-11 \mathrm{~cm})$. Mysids are common in the swash zone off sandy beaches, where they may burrow in the sand during the day or enter the water column at night (Calil and Borzone 2008), somewhat matching the occurrence of $C$. nobilis in sandy-beach environments.

The composition of the secondary items, basically other crustaceans and fish fragments, emphasizes the carnivorous habit of the species and concords with the DTTL/TL ratio. Ingestion of fish scales was also observed in other studies (Lopes and Oliveira-Silva 1998; Feitosa et al. 2002). These authors suggested that the fish scales were ingested accidentally by fish foraging close to the bottom. However, the high frequency of occurrence of scales and their considerable volume (especially in view of the small size of individual scales) made them second in importance, suggesting intentional ingestion, although this inference is not conclusive.

The high frequency and small amounts of non-identified organic matter in the stomach, together with the fact that no digestive tube was found empty, indicate that the fish feed continuously. Accidental ingestion possibly contributes to some extent, but intentional ingestion of particulate organic matter is unlikely in view of the low DTTL/TL ratio. 


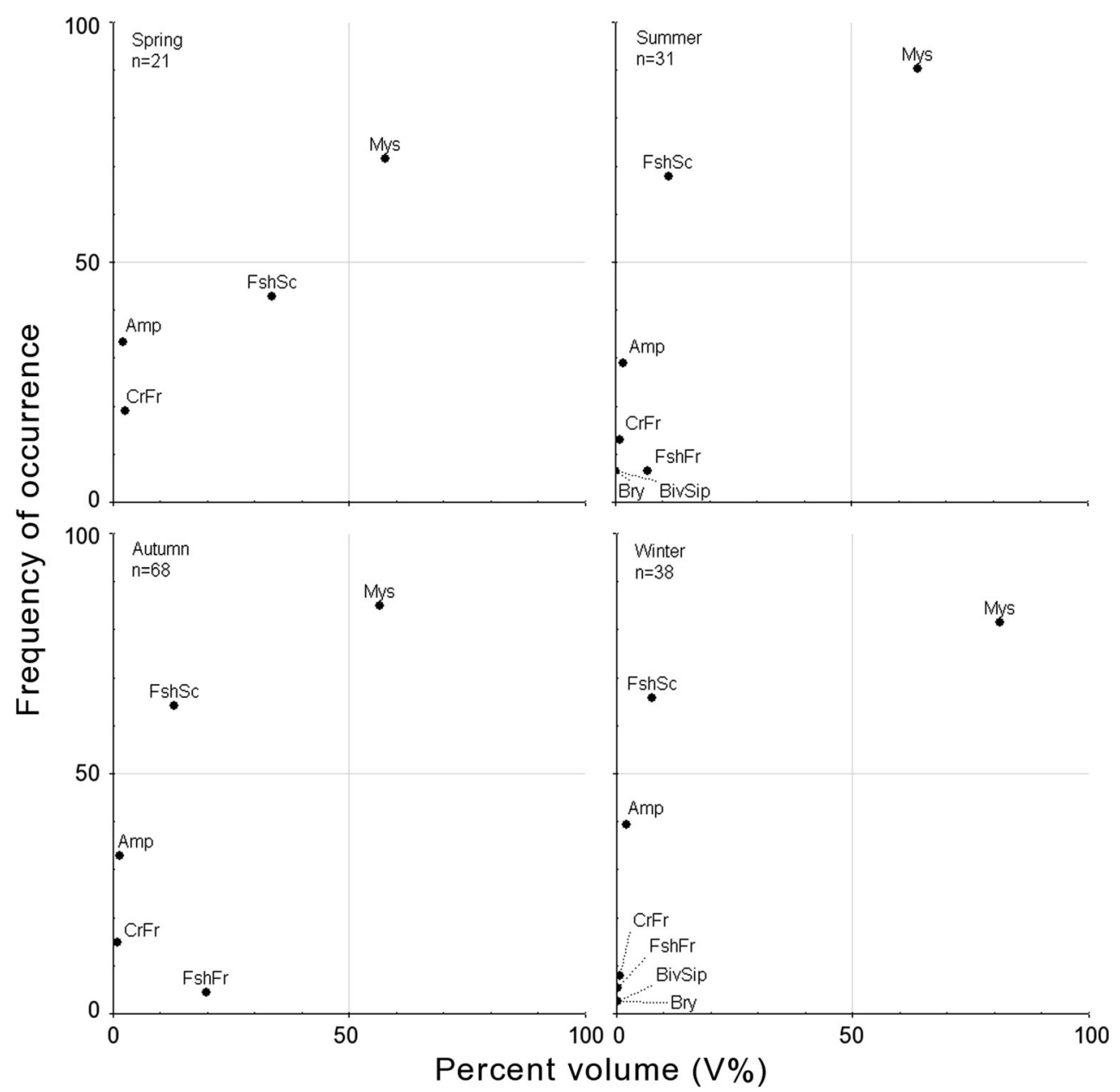

Fig. 6 Volume percentage $(V \%)$ and frequency of occurrence (FO) of each prey group found in the stomach contents of Conodon nobilis collected in Caraguatatuba Bight from August 2003 through October

Acknowledgments This study was partially financed by the Fundação de Amparo à Pesquisa do Estado de São Paulo (FAPESP) within the Biota/FAPESP-The Biodiversity Virtual Institute Program (www.biota.org.br). We also thank FAPESP for the "Programa Jovem Pesquisador em Centro Emergente" Grant awarded to $\mathrm{M}$. R. D. (Proc. No. 05/60041-6 and 06/57575-1). The Project Aware Foundation and the Padi Foundation also financed part of this research. Essential logistical support was provided by the Instituto Costa Brasilis-Desenvolvimento Sócio-Ambiental and by the Centro Universitário da Fundação de Ensino Octávio Bastos. We are grateful to A. P. Majer, G. M. Dias, and C. G. M. Delboni for their assistance in the fieldwork.

\section{References}

Anderson T (2001) Predator responses, prey refuges, and densitydependent mortality of a marine fish. Ecology 82:245-257

Barletta M, Barletta-Bergan A, Saint-paul U, Hubold G (2005) The role of salinity in structuring the fish assemblages in a tropical estuary. J Fish Biol 66:45-72. doi:10.1111/j.1095-8649.2004. 00582.x
2004. Composition is shown by season. Mys Mysida, Amp Amphipoda, $\mathrm{CrFr}$ Crustacea fragments, FishSc fish scales, FishFr fish fragments, Biv Bivalvia, BivSip Bivalvia siphons

Beverton RJH (1963) Maturation, growth and mortality of clupeid and engraulid stocks in relation to fishing. Rapports et ProcèsVerbaux des Réunions du Conseil Permanent International pour l'Exploration de la Mer 154:44-67

Branco JO, Verani JR (2006) Análise quali-quantitativa da ictiofauna acompanhante na pesca do camarão sete-barbas, na Armação do Itapocoroy, Penha, Santa Catarina. Rev Bras Zool 23: 381-391

Calil P, Borzone C (2008) Population structure and reproductive biology of Metamysidopsis neritica (Crustacea: Mysidacea) in a sand beach in south Brazil. Revista Brasileira de Zoologia 25:403-412

Cervigón F, Cipriani R, Fisher W, Garibaldi L, Hendrickx M, et al. (1992) Guía de campo de las especies comerciales marinas y de aguas salobres de la costa septentrional de Sur América. FAO Fisheries Report. Roma

Costello MJ (1990) Predator feeding strategy and prey importance: a new graphical analysis. J Fish Biol 36:261-263

Crowder LB, Murawski SA (1998) Fisheries bycatch: implications for management. Fisheries 23:8-17

da Santana FMS, Severi W (2009) Composition and structure of fish assemblage of the surf zone at Jaguaribe beach, Itamaracá (PE), Brazil. Bioikos 23:3-17 
de Dantas NCFM, Feitosa CV, Araújo ME (2012) Composition and assemblage structure of demersal fish from São Cristóvão beach, Areia Branca, RN. Biota Neotropica 12:108-117

Denadai M, Pombo M, Santos FB, Bessa E, Ferreira A, Turra A (2013) Population dynamics and diet of the Madamango Sea catfish cathorops spixii (Agassiz, 1829)(Siluriformes: Ariidae) in a tropical bight in Southeastern Brazil. PLos One 8:e81257. doi:10.1371/journal.pone.0081257

Feitosa CV, Pimenta DAS, Araújo ME (2002) Feeding habits of some fish species that live under influence of the sewerage disposal system of Fortaleza, Cerá, Brazil. Arquivo de Ciências do Mar 35:91-95

Garcia C, Duarte L (2006) Length-based estimates of growth parameters and mortality rates of fish populations of the Caribbean Sea. J Appl Ichthyol 22:193-200

Godefroid RS, Spach HL, Santos C et al (2004) Temporal changes in the abundance and diversity of the fish fauna in the shallow infralittoral of a beach, southern Brazil. Iheringia Série Zoologia 94:95-104

Hyslop E (1980) Stomach contents analysis: a review of methods and their application. J Fish Biol 17:411-429

Karachle PK, Stergiou KI (2010) Intestine morphometrics of fishes: a compilation and analysis of bibliographic data. Acta Ichthyologica Et Piscatoria 40:45-54. doi:10.3750/AIP2010.40.1.06

Kawakami E, Vazzoler G (1980) Metodo grafico e estimativa de indice alimentar aplicado no estudo de alimentacao de peixe. Boletim do Instituto Oceanográfico 29:205-207

King JR, McFarlane GA (2003) Marine fish life history strategies: applications to fishery management. Fish Manag Ecol 10:249-264. doi:10.1046/j.1365-2400.2003.00359.x

Konchina Y (1977) Some data on the biology of grunts (family Pomadasyidae). J Ichthyol 17:548-558

Lopes PRD, Oliveira-Silva JT (1998) Notes on the feeding of Conodon nobilis (Linnaeus) and Polydactylus virginicus (Linnaeus) (Actinopterygii: Haemulidae e Polynemidae) in the Jaguaribe Beach (Itamaracá Island), state of Pernambuco, Paulo. Bioikos 12:53-59

Menezes N, Figueiredo J (1980) Manual de Peixes Mari- nhos do Sudeste do Brasil. v. IV. Teleostei. 96

Oliveira AME (1974) Ictiofauna das águas estuarinas do rio Parnaíba (Brasil). Arquivo de Ciências do Mar 14:41-45
Pauly D (1979) Theory and management of tropical multispecies stocks: a review, with emphasis on the Southeast Asian demersal fisheries. ICLARM Stud Rev 1:1-35

Pauly D (1983a) Some simple methods for the assessment of tropical fish stocks. FAO Fisheries Technical Paper No. 234. Rome, Italy

Pauly D (1983b) Length-converted catch curves: a powerful tool for fisheries research in the tropics (Part I). Fishbyte Newsl Netw Trop Fish Scientists 1:9-13

Pauly D, Gaschutz G (1979) A simple method for fitting oscillating length growth data, with a program for pocket calculator. International Council for the Exploration of the Sea, Council Meeting G24, Demersal Fish Committee

Pombo M, Denadai MR, Turra A (2012) Population biology of Stellifer rastrifer, S. brasiliensis and S. stellifer in Caraguatatuba Bay, northern coast of São Paulo, Brazil. Braz J Oceanogr 60:271-282. doi:10.1590/S1679-87592012000300001

Pombo M, Denadai MR, Turra A (2013) Seasonality, dietary overlap and the role of taxonomic resolution in the study of the diet of three congeneric fishes from a tropical bay. PLoS One 8:e56107. doi:10.1371/journal.pone.0056107

Randall J (1967) Food habits of reef fishes of West Indies. Stud Trop Oceanogr 5:665-847

Rouyer T, Sadykov A, Ohlberger J, Stenseth NC (2012) Does increasing mortality change the response of fish populations to environmental fluctuations? Ecol Lett 15:658-665. doi:10.1111/ j.1461-0248.2012.01781.x

Sokal RR, Rohlf FJ (1995) Biometry. W. H. Freeman and Company, New York

Souza C (2005) Suscetibilidade morfométrica de bacias de drenagem ao desenvolvimento de inundações em áreas costeiras. Revista Brasileira de Geomorfologia 1:45-61

Taylor CC (1958) Cod growth and temperature. ICES J Mar Sci 23:366-370

Vazzoler AEAM (1996) Biologia da reprodução de peixes teleósteos: teoria e prática. EDUEM, Maringá

Walters C, Post J (1993) Density-dependent growth and competitive asymmetries in size-structured fish populations: a theoretical model and recommendations for field experiments. Trans Am Fish Soc 122:34-45 